\begin{tabular}{cc|c}
\hline Tar. Bil. Der. & Journal of Agricultural Sciences \\
& $\begin{array}{c}\text { Dergi web sayfası: } \\
\text { www.agri.ankara.edu.tr/dergi }\end{array}$ & Journal homepage: \\
& www.agri.ankara.edu.tr/journal
\end{tabular}

\title{
Growing Degree Day and Seed Yield Relationships in Mustard (Brassica juncea L.) Under Different Sowing Seasons and Locations of Turkey
}

\author{
Fatma KAYAÇETİNa ${ }^{a}$, Fadul ÖNEMLi' ${ }^{b}$, Güngör YILMAZ ${ }^{c}$, Khalid Mahmood KHAWAR ${ }^{\text {d }}$, Ahmet KINAYc, \\ Halil HATİPOĞLU ${ }^{\text {e }}$, Mehmet Niyazi KIVILCIM ${ }^{\mathrm{f}}$, Nimet KARA ${ }^{\mathrm{g}}$, Arzu KÖSE ${ }^{\mathrm{h}}$, Fırat SEFAOĞLU ${ }^{\mathrm{i}}$, Kadir \\ Aytaç ÖZAYDIN ${ }^{a}$ \\ ${ }^{a}$ Central Research Institute for Field Crops, Ankara, TURKEY \\ ${ }^{\boldsymbol{b}}$ Department of Field Crops, Faculty of Agriculture, Namik Kemal University, Tekirdağ, TURKEY \\ ${ }^{c}$ Department of Field Crops, Faculty of Agriculture, Gaziosmanpaşa University, Tokat, TURKEY \\ ${ }^{d}$ Department of Field Crops, Faculty of Agriculture, Ankara University, Ankara, TURKEY \\ ${ }^{e}$ GAP Agricultural Research Institute, Şanliurfa, TURKEY \\ $f_{\text {Cotton Research Institute, Aydin, TURKEY }}$ \\ ${ }^{g}$ Department of Field Crops, Faculty of Agriculture, Süleyman Demirel University, Isparta, TURKEY \\ ${ }^{\boldsymbol{h}}$ Transitional Zone Agricultural Research Institute, Eskişehir, TURKEY \\ ${ }^{i}$ East Anatolian Agricultural Research Institute, Erzurum, TURKEY
}

\section{ARTICLE INFO}

Research Article

DOI: 10.15832 /ankutbd. 424218

Corresponding Author: Fatma KAYAÇETIN, E-mail: fatma.kayacetin@tarimorman.gov.tr, Tel: +90 (312) 3431050

Received: 16 May 2018, Received in Revised Form: 08 July 2018, Accepted: 23 July 2018

\begin{abstract}
Mustard is grown in mild winter regions as late fall and in hard winter regions as late spring crop. Mustard has high degree of adaptability under wide range of climatic conditions in Turkey. Temperature is an important weather parameter affecting the growth and development of the mustard. The sum growing degree day (GDD) for a growing season is related to plant development which is depends on the accumulation of heat. The aim of this study was to determine the adaptation of mustard, under sowing seasons (spring and fall sowing) and locations in terms of crop growth (emergence, $50 \%$ flowering, physiological maturity, and sum growing degree days) and seed yield of mustard. Two-year field experiments in a split-plot design with four replications were carried out during 2013-14 and 2014-15 growing seasons at eight different ecological locations. These locations included Ankara, Aydın, Erzurum, Eskişehir, Isparta, Tekirdağ, Tokat and Şanlıurfa provinces of Turkey-as classified by Köppen-Geiger ecological conditions. The Brassica juncea L. (mustard seeds) were collected from wild conditions in the Konya province of Turkey. The results showed that, sowing seasons and locations significantly affected seed yield and GDD. The maximum seed yield of $3754.9 \mathrm{~kg} \mathrm{ha}^{-1}$ was obtained from Tokat (warm humid) during fall sowing with total accumulated GDD of $1512.1^{\circ} \mathrm{C}$ for mustard. Sum growing degree-days accumulated in different sowing seasons and locations occurred between $1132.0^{\circ} \mathrm{C}$ and $2285.1^{\circ} \mathrm{C}$ depending on the related ecological conditions. Fall season crop in Aydin location had the maximum growing degree days. Overall, fall season accumulated more growing degree days due to longer period of sunshine in comparison to spring season with less sunshine days resulting in longer vegetation period.
\end{abstract}

Keywords: Brassica juncea L.; Fall and spring sowing; Growing degree day; Mustard 


\section{Introduction}

Mustard is used for production of vegetable oil or biodiesel production, and for extraction of vegetable in the world (Başbağ et al 2010; Mao et al 2012). Mustard is generally grown in mild winter climates as fall crop, in hard winter climates as spring crop (Wu et al 2011). Two species of mustard Sinapis alba L. and Sinapis arvensis L. widely found in Turkey belong to Cruciferae family. These grow widely in Turkey as weed and could be commercially exploited for production of biodiesel (Blackshaw et al 2011; Kayaçetin et al 2016). Seed yield and oil quality of mustard depend on genetic, ecological conditions and agronomic factors interactions among them (Johnson et al 2003). Temperature is a major factor that affects and determines crop growth, development and productivity (Qadir et al 2007; Kaleem et al 2009; Singh \& Lallu-Singh 2014). Mustard plant behave differently under different sowing seasons and environmental conditions that are based on temperature prevailing during the crop life cycle. Variation in maximum and minimum temperature largely alters the growth pattern of the crop by affecting the duration as well as onset of different phenophases. Quantification of the effect of temperature on crop growth can best be evaluated by GDD (mean ambient temperature minus the threshold temperature required for survival of crop). This quantification helps to quantify the thermal requirement for the start of different phenophases of crops (Dutta et al 2011). There are certain base temperatures for each plant species (Morrison et al 1989). Different sowing seasons and locations might cause different environmental conditions from emergence to maturity. The accumulation of GDD determines the maturity of crop and yield. According to Miller et al (2001) mustard cultivars are available, each with specific GDD requirements, for emergence 110-136, for flowering 680-750, for maturity ranging from 1510 to 1610 growing degree days using a $5{ }^{\circ} \mathrm{C}$ base temperature. The best growth of mustard occurs between 12 and 25 ${ }^{\circ} \mathrm{C}$. The optimum temperature for maximum and minimum growth and development are estimated at just over $20{ }^{\circ} \mathrm{C}$ and $5{ }^{\circ} \mathrm{C}$ in the same order. GDD has influenced the productivity and profitability of mustard under different weather conditions in locations and sowing seasons (Ghosh \& Chatterjee 1988; Wahhab et al 2002).

The target of this study was to determine the adaptation of mustard, in two sowing seasons (spring and fall) and differently selected Köppen-Geiger ecological locations of Turkey in terms of crop growth (emergence, 50\% flowering, physiological maturity, and sum growing degree days) and seed yield.

\section{Materials and Methods}

The study was conducted during the growing seasons of 2013-14 and 2014-15 under the Ankara (warm tempetare climates, dry summer, warm summer-Csb), Aydin (warm tempetare climates, dry summer, hot summer-Csa), Erzurum (snow climates, fully humid, warm summer-Dfb), Eskişehir (snow climates, summer dry, warm summer-Dsb), Isparta (warm tempetare climates, dry summer, hot summerCsa), Tekirdağ (warm tempetare climates, dry summer, hot summer-Csa), Tokat (snow climates, summer dry, warm summer-Dsb) and Şanlıurfa (arid climates, steppe, cold arid-BSk) Köppen-Geiger ecological conditions of Turkey (Kottek et al 2006; https://en.climate-data.org 2018).

The seeds of mustard used in this study were selected from the plants growing under wild conditions in the Konya province. The identification of the plants was carried out by Department of Biology, Gazi University, Ankara, Turkey. Treatment combinations were arranged in a splitplot design with 4 replication, at all locations during both years. The effect of locations was studied in the main plots and fall-spring sowing in the subplots. Plot length was $5 \mathrm{~m}$ and consisted of 10 rows $(30 \mathrm{~cm})$. The sowing dates were determined for favorable climatic conditions at all locations. Nitrogen, phosphorus and sulphur fertilizers were applied at the rate of 100,50 and $35 \mathrm{~kg} \mathrm{ha}^{-1}$ in the form of diammonium phosphate, ammonium nitrate and ammonium sulfate respectively (Pyare et al 2008). The total quantity of phosphorus and 
sulphur fertilizer was applied at the time of sowing. Total nitrogen fertilization was applied in two equal doses, at the time of sowing and rosette formation. No irrigation was done to the experimental plots during the two years study period.

The soil samples took from each location at a depth of 0-20 and 21-40 cm during two analysed for the minerals, organic contents texture, the saturation percentage, total salts, $\mathrm{pH}$, lime, phosphorus, potassium and organic contents. The soil samples charachteristics belonging to each experimental areas are shown in Table 1. All soils had low organic contents in range of low inorganic matter (Table 1).

Table 1- Physical and chemical soil charachteristics of the experimental areas sampled at depth of 0-20 and $21-40 \mathrm{~cm}$

\begin{tabular}{|c|c|c|c|c|c|c|c|c|c|c|}
\hline Location & Year & $\begin{array}{c}\text { Depth } \\
(\mathrm{cm})\end{array}$ & Texture & $\begin{array}{c}\text { Saturation } \\
\text { percentage } \\
(\%)\end{array}$ & $\begin{array}{c}\text { Total salt } \\
(\%)\end{array}$ & $p H$ & $\begin{array}{l}\text { Lime } \\
(\%)\end{array}$ & $\begin{array}{c}\text { Phosphorus } \\
(P)\end{array}$ & $\begin{array}{l}\text { Potassium } \\
(K)\end{array}$ & $\begin{array}{c}\text { Organic } \\
\text { Contents } \\
(\%)\end{array}$ \\
\hline \multirow{4}{*}{ Ankara } & \multirow{2}{*}{ 2013-14 } & $0-20$ & Clay loam & 64.0 & 0.041 & 7.79 & 28.12 & 6.63 & 162.04 & 1.31 \\
\hline & & $21-40$ & Clay loam & 63.0 & 0.035 & 7.85 & 27.40 & 4.87 & 149.86 & 1.31 \\
\hline & \multirow{2}{*}{ 2014-15 } & $0-20$ & Clay loam & 63.0 & 0.028 & 7.75 & 31.45 & 7.35 & 234.55 & 0.90 \\
\hline & & $21-40$ & Clay loam & 63.0 & 0.037 & 7.76 & 24.82 & 7.81 & 219.99 & 1.49 \\
\hline \multirow{4}{*}{ Aydın } & \multirow{2}{*}{ 2013-14 } & $0-20$ & Loam & 49.0 & 0.017 & 8.00 & 14.23 & 22.29 & 52.61 & 0.53 \\
\hline & & $21-40$ & Loam & 49.0 & 0.017 & 8.06 & 13.98 & 17.17 & 50.13 & 1.16 \\
\hline & \multirow{2}{*}{ 2014-15 } & $0-20$ & Clay loam & 51.0 & 0.028 & 7.90 & 13.29 & 19.17 & 77.10 & 1.30 \\
\hline & & $21-40$ & Clay loam & 51.0 & 0.029 & 7.96 & 16.41 & 15.86 & 63.00 & 1.45 \\
\hline \multirow{4}{*}{ Erzurum } & \multirow{2}{*}{ 2013-14 } & $0-20$ & Loam & 50.0 & 0.018 & 7.93 & 5.94 & 11.23 & 105.60 & 0.64 \\
\hline & & $21-40$ & Clay loam & 51.0 & 0.018 & 7.98 & 6.20 & 12.77 & 92.44 & 0.53 \\
\hline & \multirow{2}{*}{$2014-15$} & $0-20$ & Clay loam & 54.0 & 0.450 & 7.80 & 5.99 & 9.61 & 109.02 & 0.97 \\
\hline & & $21-40$ & Clay loam & 52.0 & 0.254 & 7.84 & 5.17 & 9.68 & 86.15 & 1.20 \\
\hline \multirow{4}{*}{ Eskişehir } & \multirow{2}{*}{ 2013-14 } & $0-20$ & Clay loam & 61.0 & 1.000 & 8.08 & 10.99 & 8.59 & 132.00 & 3.45 \\
\hline & & $21-40$ & Clay loam & 60.0 & 0.836 & 7.99 & 8.06 & 8.51 & 136.00 & 3.87 \\
\hline & \multirow{2}{*}{ 2014-15 } & $0-20$ & Clay loam & 58.0 & 0.043 & 7.57 & 22.55 & 7.96 & 105.60 & 1.53 \\
\hline & & $21-40$ & Clay loam & 58.0 & 0.039 & 7.71 & 20.17 & 8.25 & 102.24 & 1.71 \\
\hline \multirow{4}{*}{ Isparta } & \multirow{2}{*}{ 2013-14 } & $0-20$ & Loam & 45.0 & 0.011 & 7.88 & 31.19 & 7.08 & 40.74 & 0.26 \\
\hline & & $21-40$ & Clay loam & 53.0 & 0.014 & 7.83 & 30.44 & 5.04 & 89.27 & 0.14 \\
\hline & \multirow{2}{*}{ 2014-15 } & $0-20$ & Loam & 43.0 & 0.011 & 7.88 & 30.55 & 3.69 & 145.90 & 0.67 \\
\hline & & $21-40$ & Loam & 42.0 & 0.008 & 7.93 & 32.93 & 4.68 & 149.86 & 0.99 \\
\hline \multirow{4}{*}{ Tekirdağ } & \multirow{2}{*}{ 2013-14 } & $0-20$ & Clay loam & 53.0 & 0.022 & 7.88 & 8.10 & 5.18 & 92.44 & 0.13 \\
\hline & & $21-40$ & Clay loam & 52.0 & 0.022 & 7.83 & 8.21 & 4.05 & 40.74 & 0.25 \\
\hline & \multirow{2}{*}{ 2014-15 } & $0-20$ & Clay loam & 57.0 & 0.032 & 7.30 & 0.74 & 7.32 & 57.70 & 1.61 \\
\hline & & $21-40$ & Clay loam & 56.0 & 0.016 & 7.62 & 0.74 & 6.57 & 52.61 & 1.37 \\
\hline \multirow{4}{*}{ Tokat } & \multirow{2}{*}{ 2013-14 } & $0-20$ & Loam & 46.0 & 0.015 & 7.74 & 11.85 & 7.44 & 43.01 & 0.40 \\
\hline & & $21-40$ & Loam & 46.0 & 0.018 & 7.79 & 11.28 & 5.16 & 34.21 & 0.55 \\
\hline & \multirow{2}{*}{ 2014-15 } & $0-20$ & Clay loam & 51.0 & 0.022 & 7.64 & 11.65 & 8.05 & 65.72 & 1.27 \\
\hline & & $21-40$ & Loam & 49.0 & 0.023 & 7.57 & 15.41 & 5.39 & 32.14 & 1.18 \\
\hline \multirow{4}{*}{ Şanlıurfa } & \multirow{2}{*}{ 2013-14 } & $0-20$ & Clay loam & 69.0 & 0.045 & 7.68 & 30.00 & 6.01 & 160.80 & 1.74 \\
\hline & & $21-40$ & Clay loam & 68.0 & 0.053 & 7.73 & 30.00 & 2.63 & 72.00 & 1.49 \\
\hline & \multirow{2}{*}{ 2014-15 } & $0-20$ & Clay loam & 54.0 & 0.023 & 7.98 & 32.93 & 4.05 & 102.24 & 0.75 \\
\hline & & $21-40$ & Clay loam & 55.0 & 0.026 & 8.02 & 32.78 & 1.85 & 71.31 & 0.25 \\
\hline
\end{tabular}

Data were obtained from Soil Fertilizer and Water Resources Institute 
Daily maximum and minimum temperature value (\%) of the 2013-14 and 2014-15 vegetation periots of mustard are presented in Table 2; Montly rainfall, minimum and maximum temperatures values recorded during mustard development in experimental areas are presented in Figure 1. During

Table 2- Monthly maximum and minimum temperature value (\%) of the 2013-14 and 2014-15 vegetation periods of mustard

\begin{tabular}{|c|c|c|c|c|c|c|c|c|c|c|c|c|}
\hline \multirow{3}{*}{ Location } & \multicolumn{4}{|c|}{ September } & \multicolumn{4}{|c|}{ October } & \multicolumn{4}{|c|}{ November } \\
\hline & \multicolumn{2}{|c|}{$2013-14$} & \multicolumn{2}{|c|}{$2014-15$} & \multicolumn{2}{|c|}{$2013-14$} & \multicolumn{2}{|c|}{$2014-15$} & \multicolumn{2}{|c|}{$2013-14$} & \multicolumn{2}{|c|}{$2014-15$} \\
\hline & Max. & Min. & Max. & Min. & Max. & Min. & Max. & Min. & Max. & Min. & Max. & Min. \\
\hline Ankara & 25.14 & 11.03 & 25.18 & 13.48 & 9.33 & 4.86 & 19.21 & 8.65 & 15.30 & 2.980 & 12.51 & 3.54 \\
\hline Aydın & 2.01 & 16.99 & 31.35 & 18.22 & 5.64 & 11.17 & 26.57 & 14.53 & 20.16 & 9.90 & 19.34 & 9.36 \\
\hline Erzurum & 1.29 & 3.93 & 23.01 & 5.18 & 13.49 & -2.45 & 14.92 & 2.48 & 8.27 & -4.63 & 6.78 & -5.04 \\
\hline Isparta & 6.22 & 10.45 & 24.89 & 11.71 & 19.14 & 3.76 & 19.53 & 7.56 & 15.64 & 3.17 & 13.06 & 2.12 \\
\hline Tekirdă̆ & 5.55 & 17.17 & 24.97 & 16.78 & 8.08 & 11.02 & 19.12 & 12.35 & 15.93 & 9.90 & 14.40 & 8.72 \\
\hline \multirow[t]{2}{*}{ Tokat } & 5.72 & 11.34 & 27.56 & 14.02 & 8.78 & 5.53 & 20.36 & 9.49 & 5.11 & 4.15 & 12.13 & 3.02 \\
\hline & \multicolumn{4}{|c|}{ December } & \multicolumn{4}{|c|}{ January } & \multicolumn{4}{|c|}{ February } \\
\hline \multirow[t]{2}{*}{ Location } & \multicolumn{2}{|c|}{$2013-14$} & \multicolumn{2}{|c|}{ 2014-15 } & \multicolumn{2}{|c|}{ 2013-14 } & \multicolumn{2}{|c|}{ 2014-15 } & \multicolumn{2}{|c|}{$2013-14$} & \multicolumn{2}{|c|}{$2014-15$} \\
\hline & Max. & Min. & Max. & Min. & Max. & Min. & Max. & Min. & Max. & Min. & Max. & Min. \\
\hline Ankara & 3.71 & -4.51 & 9.54 & 3.00 & 7.33 & 0.07 & 5.00 & -1.86 & 11.73 & 0.52 & 7.94 & 0.47 \\
\hline Aydın & 13.27 & 3.60 & 16.38 & 8.63 & 16.00 & 7.50 & 12.74 & 4.75 & 7.10 & 6.46 & 14.33 & 5.53 \\
\hline Isparta & 7.14 & -3.35 & 10.7 & 2.86 & 9.41 & -0.30 & 6.27 & -1.59 & 2.12 & -0.14 & 7.81 & 0.05 \\
\hline Tekirdă̆ & 9.66 & 3.18 & 12.31 & 6.84 & 11.16 & 5.32 & 9.17 & 2.82 & 11.64 & 5.66 & 10.04 & 4.28 \\
\hline Tokat & 2.56 & -4.21 & 10.81 & 3.64 & 9.50 & -0.06 & 6.90 & -1.33 & 3.18 & 3.06 & 10.31 & 1.88 \\
\hline \multirow[t]{2}{*}{ Şanlıurfa } & 9.66 & 3.18 & 12.31 & 6.84 & 1.16 & 5.32 & 9.17 & 2.826 & 11.64 & 5.66 & 10.04 & 4.28 \\
\hline & \multicolumn{4}{|c|}{ March } & \multicolumn{4}{|c|}{ April } & & & & \\
\hline Location & 201 & & 201 & & 201. & & 201 & & 2013 & & 2014 & \\
\hline & Max. & Min. & Max. & Min. & Max. & Min. & Max. & Min. & Max. & Min. & Max. & Min. \\
\hline Ankara & 14.58 & 2.76 & 12.56 & 3.05 & 19.77 & 7.28 & 14.90 & 3.41 & 22.61 & 10.59 & 23.28 & 10.80 \\
\hline Aydın & 19.38 & 7.98 & 17.75 & 7.89 & 23.36 & 11.64 & 21.98 & 9.38 & 27.83 & 15.07 & 29.58 & 15.50 \\
\hline Erzurum & 8.22 & -3.40 & 4.52 & -7.12 & 14.24 & 0.66 & 11.10 & -0.35 & 18.45 & 4.60 & 17.33 & 3.09 \\
\hline Isparta & 12.95 & 1.95 & 11.70 & 2.26 & 17.26 & 5.30 & 15.33 & 2.81 & 20.76 & 8.71 & 22.75 & 8.82 \\
\hline Tekirdağ & 14.10 & 6.36 & 11.40 & 6.01 & 17.18 & 10.03 & 15.80 & 7.74 & 21.61 & 13.61 & 22.85 & 14.56 \\
\hline Tokat & 16.02 & 4.88 & 13.72 & 3.74 & 22.60 & 8.64 & 16.27 & 5. & 24.47 & 11.60 & 24.54 & 10.83 \\
\hline Şanlıurfa & 4.10 & 6.36 & 11.40 & 6.012 & 17.18 & 10.03 & 15.80 & 7.74 & 1.61 & 13.61 & 22.85 & 14.56 \\
\hline & & & & & & & & & & & & \\
\hline Location & 2013 & & 201 & & 201 & & 2012 & & 2013 & & 2014 & \\
\hline & Max. & Min. & Max. & Min. & Max. & Min. & Max. & Min. & Max. & Min. & Max. & Min. \\
\hline Ankara & 26.52 & 13.41 & 24.57 & 13.31 & 32.31 & 18.29 & 31.19 & 16.97 & 32.93 & 18.41 & 31.60 & 17.78 \\
\hline Aydın & 32.65 & 18.84 & 31.31 & 18.42 & 36.08 & 21.23 & 37.62 & 22.05 & 37.05 & 22.36 & 37.58 & 22.61 \\
\hline Erzurum & 23.51 & 6.31 & 24.28 & 6.79 & 29.25 & 11.44 & 29.50 & 10.05 & 30.54 & 11.66 & 29.67 & 10.92 \\
\hline Isparta & 26.42 & 12.51 & 24.82 & 11.28 & 31.32 & 16.23 & 31.28 & 15.96 & 32.35 & 16.39 & 31.23 & 16.17 \\
\hline Tekirdağ & 26.16 & 17.70 & 25.80 & 17.32 & 29.17 & 20.17 & 29.51 & 19.92 & 30.08 & 20.89 & 30.47 & 21.75 \\
\hline Tokat & 27.97 & 14.00 & 26.11 & 14.60 & 31.95 & 17.50 & 29.21 & 15.59 & 32.79 & 18.91 & 31.31 & 18.46 \\
\hline Şanlıurfa & 26.16 & 17.70 & 25.80 & 17.32 & 29.17 & 20.17 & 29.51 & 19.92 & 30.08 & 20.89 & 30.47 & 21.75 \\
\hline
\end{tabular}

Data were obtained from the Directorate of State Meteorological Observatory at Ankara 
the vegetation period in 2013-14 and in 2014-15. There was total of 302.2 and $603.0 \mathrm{~mm}$, average temperature of $11.4{ }^{\circ} \mathrm{C}$ and $12.3{ }^{\circ} \mathrm{C}$, and an average humidity of $55.5 \%$ and $69.3 \%$ in Ankara. There was total of 302.2 and $603.0 \mathrm{~mm}$, average temperature of $17.9{ }^{\circ} \mathrm{C}$ and $17.4{ }^{\circ} \mathrm{C}$, and an average humidity of $58.6 \%$ and $63.9 \%$ in Aydin. There was total of 317.7 and $467.9 \mathrm{~mm}$, average temperature of $6.4{ }^{\circ} \mathrm{C}$ and $6.4^{\circ} \mathrm{C}$, and an average humidity of $65.3 \%$ and $68.4 \%$ in Erzurum. There was total of 257.4 and $571.9 \mathrm{~mm}$,
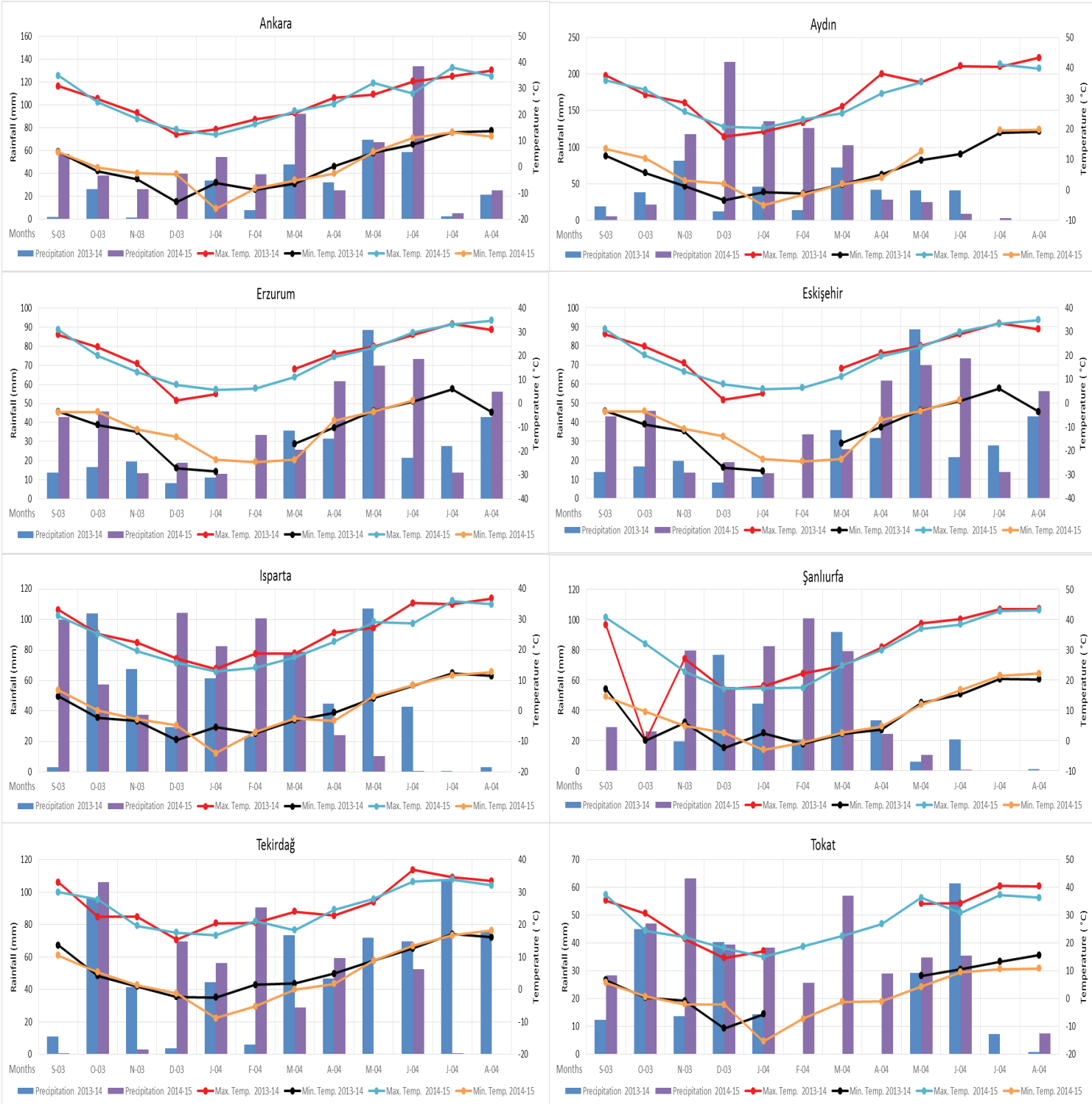

Figure 1- Monthly rainfall, minimum and maximum temperatures values recorded during mustard development in experimental areas $(\mathrm{S}$, September; O, October; N, November; D, December; J, January; F, February; M, March; A, April; M, May; J, June; J, July; A, August) 
average temperature of $12.7^{\circ} \mathrm{C}$ and $11.1^{\circ} \mathrm{C}$, and an average humidity of $62.2 \%$ and $73.3 \%$ in Eskişehir. There was total of 565.9 and $596.6 \mathrm{~mm}$, average temperature of $12.6{ }^{\circ} \mathrm{C}$ and $11.9^{\circ} \mathrm{C}$, and an average humidity of $57.1 \%$ and $63.4 \%$ in Isparta. There was total of 647.9 and $468.7 \mathrm{~mm}$, average temperature of $15.4{ }^{\circ} \mathrm{C}$ and $14.5^{\circ} \mathrm{C}$, and an average humidity of $77.1 \%$ and $78.1 \%$ in Tekirdağ. There was total of 224.8 and $406.7 \mathrm{~mm}$, average temperature of 14.4 ${ }^{\circ} \mathrm{C}$ and $13.3{ }^{\circ} \mathrm{C}$, and an average humidity of $52.1 \%$ and $62.4 \%$ in Tokat. There was total of 313.8 and $487.0 \mathrm{~mm}$, average temperature of $18.6^{\circ} \mathrm{C}$ and 18.9 ${ }^{\circ} \mathrm{C}$, and an average humidity of $41.4 \%$ and $50.6 \%$ in Şanlıurfa (Figure 1).

Emergence, 50 percent flowering and physiological maturity were identified based on visual observations. Growing degree days requirement for attaining different phenological events were calculated from weather data recorded through out crop life cycle by the following equation (Berti \& Johnson 2008).

$\mathrm{GDD}=\Sigma\left[\left[\left(T_{\max }+T_{\min }\right) / 2\right]-T_{\text {base }}\right]$

$T_{\max }$ and $T_{\min }$ are daily maximum and minimum air temperatures in degree centigrade, respecticely. $T_{\text {base }}$ is the $5^{\circ} \mathrm{C}$ base temperature for mustard development (Stannard et al 2000). Daily maximum and minimum air temperature data from eight locations are used in the study. GDD were accumulated by adding each day's GDD contribution as the season progressed.

Seed yield data were subjected to analysis of variance (ANOVA) using the MSTAT-C computer Statistical software. The significant differences among group means were separated using Duncan's Multiple Range Test.

\section{Results and Discussion}

Effects of sowing season and locations on growing degree days from emergence to maturity and seed yield of mustard are presented in Table 3 . Emergence, flowering, maturity, sum growing degree days and seed yield of mustard varied according to sowing seasons, years and locations. Sum growing degree-days were accumulated between $1473.0{ }^{\circ} \mathrm{C}$ and $2098.9{ }^{\circ} \mathrm{C}$ during 2013-14 and $1132.0^{\circ} \mathrm{C}$ and $2008.2^{\circ} \mathrm{C}$ during $2014-15$ under conditions of varied ecological conditions.

In fall sowing, no results could be obtained because of cold damage at Ankara, Eskişehir and Isparta locations during 2013-14. No emergence was noted at Erzurum, despite irrigation for both years due to high coldness.

The seed yield (1847.5 $\left.\mathrm{kg} \mathrm{ha}^{-1}\right)$ of the second year was higher than the first year $\left(1146.9 \mathrm{~kg} \mathrm{ha}^{-1}\right)$ (Table 3). This differences were occured due to higher rainfall during the growing period of plants during second year. Degree days from sowing to emergence in all locations was earlier at Tokat and Şanliurfa compared to other locations during 201314, whereas it was earlier at Ankara compared to other locations during 2014-15. Flowering was earlier at Tokat compared to other locations during 2013-14, at Ankara compared to other locations during 2014-15. Degree days from sowing to maturity at all locations was earlier at Tokat during 2013-14, at Ankara in 2014-15 compared to other locations. Different locations exhibited differences for growing degree days (GDD) accumulation during both years. Sowing season is important for higher seed yield. Soil moisture is the major constraint for seed germination as well as for plant establishment and plays a key role under rainfed conditions, besides temperature. Statistically significant differences were found between the two consecutive years in terms of seed yield of mustard. The highest seed yield (1962.5 and $3754.9 \mathrm{~kg} \mathrm{ha}^{-1}$ ) was obtained at Aydın and Tokat, and the total GDD of mustard accumulated between 1473.0 and $2098.9^{\circ} \mathrm{C}$ during 2013-14 and 1132.0 and 2008.2 ${ }^{\circ} \mathrm{C}$ during 2014-15, respectively. Total GDD of mustard increased at Aydin during both years, but its seed yield did not increase during both years. Aydin location had higher rainfall during the growing period of plants in the second year $(791.0 \mathrm{~mm})$ compared to the first year $(407.8 \mathrm{~mm})$. However, the seed yield in the second year was lower compared to first year due to diseases and long drought period before flowering (İptaş \& Kolsarıcı 1988). At Tokat location, rainfall during the growing period 


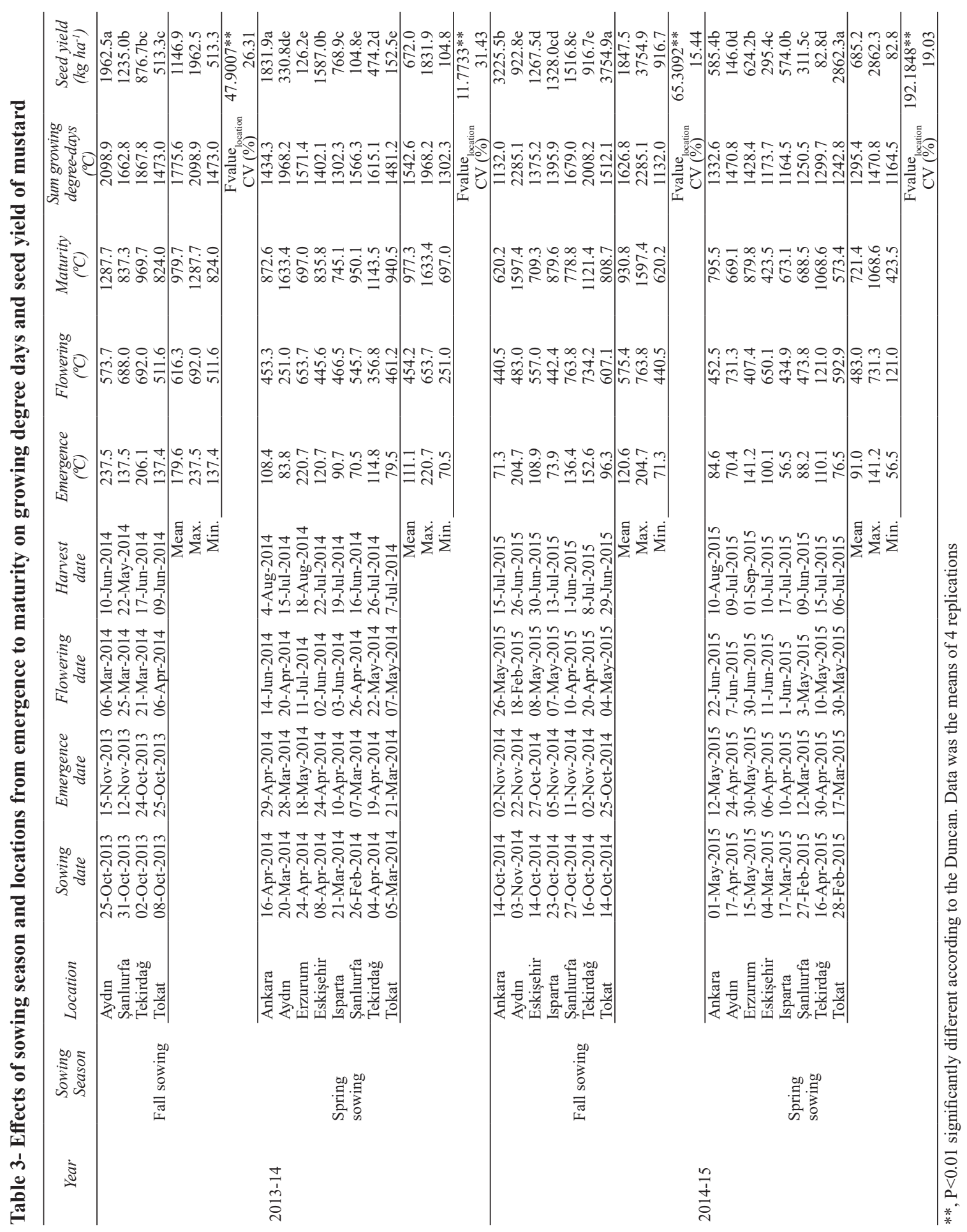


of plants during the second year $(406.7 \mathrm{~mm})$ was higher compared to the first year $(224.8 \mathrm{~mm})$. Low temperatures at flowering and maturity during 20142015 prolonged vegetation period and provided suitable environmental conditions for good growth (Schuster \& Taghizadeh 1981; Kondra et al 1983). Due to higher regular and sufficient rainfall $(90.75$ $\mathrm{mm}$ ) during the flowering and maturity (MarchApril-May-June) of second year growing season compared to the first year $(56.5 \mathrm{~mm})$ at Tokat locations. The second year seed yield was higher compared to the first year. The results of the previous studies support that the differences in yield could be derived from various years and locations which have different ecological conditions including air temperature, precipitation and agronomic practices (Saran \& Giri 1987; Shafii et al 1992; Walton \& Bowden 1999).

In spring sowing, the seed yield $\left(685.2 \mathrm{~kg} \mathrm{ha}^{-1}\right)$ of the second year was higher compared to the yield of the first year $\left(672.0 \mathrm{~kg} \mathrm{ha}^{-1}\right)$ (Table 3$)$. This differences was a result of raising rainfall and air temperature during the growing period of plants.

Comparing GDD from sowing to emergence among all locations; it varied. It was earlier at Şanlıurfa and Isparta during 2013-14 and during 2014-15 compared to other locations in the same order. Flowering was shorter at Aydin compared to other locations during 2014. Flowering was shorter at Tekirdağ compared to other locations in 2015. Degree days from sowing to maturity within all locations was obtained earlier at Erzurum and Eskişehir during 2014 and 2015 compared to other locations.

Statistically significant differences were found between the two consecutive years in terms of seed yield of mustard. The highest seed yield (1831.9 and $2862.3 \mathrm{~kg} \mathrm{ha}^{-1}$ ) was obtained at Ankara and Tokat locations. The total GDD of mustard at Ankara and Tokat was obtained between 1302.3 and 1968.2 ${ }^{\circ} \mathrm{C}$ during 2014 and 1164.5 and $1470.8{ }^{\circ} \mathrm{C}$ during 2015, respectively. Sum GDD of mustard was observed the highest at Aydın during both years, but without increase in seed yield. The germination, growth, flowering stages, and ripening periods of the plants were determined as by temperatures and genetic factors. Environmental factors, especially temperature during the growing period of the plants is important. Especially, during flowering and ripening, as high temperatures and water stress caused decreases in seed yield (Hocking et al 1997; Kaleem et al 2010). The threshold temperature during flowering, resulting in seed yield losses, was $29.5^{\circ} \mathrm{C}$ and high mean maximum temperature during vegetative development caused a reduction in induction of number of flowers for all of the tested Brassica species (Malcolm et al 2002). The precipitation of 69.2 and $58.6 \mathrm{~mm}$ during flowering, began and continued through May and June until the maturity of capsules after fertilization that affected positively during 2014. Erzurum had the highest altitude among locations; where the plants were not able to complete theire vegetative growth and entered generative phase at an earlier stage of growth that resulted in non development of their morphological features before generative maturity, therefore this affected completation of grain formation and yield. Thus, the grains were quite weak and feeble (Amirnia et al 2012). Varying results in yields among locations clearly demonstrated that, these differences among locations could be due to varying air temperatures, precipitation (Sra 1978; Christensen et al 1985; Walton \& Bowden 1999).

Variation in maximum and minimum temperature largely alters the growth pattern of the crop by affecting the duration as well as onset of different phenophases. Quantification of the effects of temperature on crop growth can best be evaluated by GDD (mean ambient temperature minus the threshold temperature required for survival of crop). This quantification helps to know the thermal requirement for the start of different phenophases of crops (Dutta et al 2011). According to Miller et al (2001) mustard cultivars are available, each with specific GDD requirements, for emergence 110-136, for flowering 680-750, for maturity ranging from 1510 to 1610 growing degree days using a $5^{\circ} \mathrm{C}$ base temperature. It is a cool loving crop with thermo and photo-sensitivity (Ghosh \& Chatterjee 1988). 
The best growth of mustard occurs between 12 and $25^{\circ} \mathrm{C}$. The optimum temperature for maximum and minimum growth and development are estimated at just over $20{ }^{\circ} \mathrm{C}$ and $5{ }^{\circ} \mathrm{C}$ in the same order. GDD has influenced the productivity and profitability of mustard under different weather conditions in locations and sowing seasons (Wahhab et al 2002).

In fall sowing, GDD were accumulated between 1473.0 and $2098.9^{\circ} \mathrm{C}$ during 2013-14 and between 1132.0 and $2285.1{ }^{\circ} \mathrm{C}$ during 2014-2015. Seed yield was obtained from 513.3 to $1962.5 \mathrm{~kg} \mathrm{ha}^{-1}$ during 2013-14 and from 916.7 to $3754.9 \mathrm{~kg} \mathrm{ha}^{-1}$ during 2014-2015. In spring sowing, GDD were accumulated between 1302.3 and $1968.2^{\circ} \mathrm{C}$ during 2014 and 1164.5 and between $1628.4{ }^{\circ} \mathrm{C}$ during 2015 depending on sowing dates under locations and ecological conditions. Seed yield in spring sowing was between 104.8 and $1831.9 \mathrm{~kg} \mathrm{ha}^{-1}$ during 2013-14 and between 82.8 and $2862.3 \mathrm{~kg} \mathrm{ha}^{-1}$ during 2014-2015. The results of this research showed that the locations and sowing seasons of mustard affected growing degree days for emergence, $50 \%$ flowering and physiological maturity during both years. Sum GDD of mustard increased at Aydin during both years compared to other locations, but its seed yield remained unchanged. This confirms that GDD accumulation plays a important role for higher seed yields. However, not only rainfall but also low and high temperatures are usually the most limiting factors for crop growth (Loss \& Siddique 1994). Vegetative growth rate is also restricted by low temperatures $\left(0-7{ }^{\circ} \mathrm{C}\right)$ in mid-winter and seed yield is adversely affected by high temperatures (25$40{ }^{\circ} \mathrm{C}$ ) at the end of the season in spring and early summer (Turner et al 2001).

\section{Conclusions}

Different sowing seasons and locations might cause different environmental conditions from emergence to maturity. The accumulation of GDD determines the maturity of crop and yield. The target of this study was to determine the adaptation of mustard, in two sowing seasons (spring and fall) and differently selected Köppen-Geiger ecological locations of Turkey in terms of crop growth (emergence, 50\% flowering, physiological maturity, and sum growing degree days) and seed yield. The Turkey is facing acute shortage of underground water levels and there is need to grow high vegetable oil producing crops suitable for biodiesel production with minimum input. This study reports the feasibility of mustard cultivation in different climatic zones of Turkey based on GDD or heat unit availability during the growing season and evaluates two years data. This evaluation report suggests minimum GDD for identifying useful sowing dates for harvesting profitable oil yield. In addition, the experimental locations lying in the North and West of Turkey were more useful, compared to the Erzurum location lying in the cold location with insufficient GDD suggesting non suitability of the location for commercial cultivation of mustard. These results clearly show that mustard is a suitable alternative crop for warm climatic regions of Turkey, irrespective of the location. It is assumed that there is a high potential of mustard for cultivation under arid climatic conditions of Turkey irrespective of the type of soil and environmental relative humidity status, if the farmers could be convinced to grow mustard in provinces that could accumulate GDD of at least $1132.0{ }^{\circ} \mathrm{C}$. Differences among various locations might be due to the different climatic conditions that are based on prevailing temperatures during the growing period of mustard at these locations. The plants from fall sowing showed increased seed yield compared to the plants obtained from spring sowing; because mustard has tendency to mature (completes its life cycle) earlier (short duration) by accumulating less heat units.

\section{Acknowledgements}

We would like to thank Prof. Dr. Hayri DUMAN (Department of Biology, Gazi University, Ankara, Turkey) for the identification of the plants.

\section{References}

Amirnia R, Ghiyasi M \& Tajbakhsh M (2012). Farklı gelişme yüksekliklerin hardal otunun (Sinapis arvensis L) bazı özellikleri üzerine etkisi. Tarım Bilimleri Araştırma Dergisi 5(2): 144-147 
Başbağ M, Demirel R \& Avcı M (2010). Some quality traits of different wild plants. Science Biology 2(1): 36-39

Berti M T \& Johnson B L (2008). Growth and development of cuphea. Industrial Crops and Products 27: 265-271

Blackshaw R, Johnson E, Gan Y, May W, McAndrew D, Barthet V, McDonald T \& Wispinski D (2011). Alternative oilseed crops for biodiesel feedstock on the Canadian prairies. Canadian Journal of Plant Science 9(5): 889-896

Christensen J V, Legge W G, Depauw R M, Hennig A M F, McKenzie J S, Siemens B \& Thomos J B (1985). Effect of seeding date, nitrogen and phosphate fertilizer on growth, yield and quality of rapeseed in Northwest Alberta. Canadian Journal of Plant Science 65: 275-284

Dutta A, Dutta S K, Jena S, Nath R, Bandyopadhyay P \& Chakraborty K (2011). Effect of growing degree days on biological growth indices of wheat and mustard. Journal of Crop and Weed 7(1): 70-76

Ghosh R K \& Chatterjee B N (1988). Effect of dates of sowing on oil content and fatty acid profiles of Ministry of Indian mustard. Indian Journal Oil Seed Research 5: 144-149

Hocking P J, Kirkegaard J A, Angus J F, Gibson A H \& Koet E A (1997). Comporison of canola Indian mustard and linola in two contrasting environments. I. Effects of nitrogen fertilizer on dry-matter production seed yield and seed quality. Field Crop Research 49(2-3): 107-125

İptaş S \& Kolsarıcı Ö (1988). Yabancı kökenli yağlık ve yemlik kolza (Brassica napus ssp oleifera L) çeşitlerinin tarımsal özelliklerinin karşılaştırılması. Ankara Ünversitesi Ziraat Fakültesi Yıllı̆̆ı 39(1-2): 267-277

Johnson B L, Zakaria A K M \& Hanson B K (2003). Row spacing interaction on spring canola performance in the North Great Plains. Agronomy Journal 95(3): 703708

Kaleem S, Hassan F U \& Saleem A (2009). Influence of environmental variations on physiological attributes of sunflower. African Journal of Biotechnology 8: 3531-3539

Kaleem S, Hassan F U \& Razzaq A (2010). Growth rhythms in sunflower (Helianthus annuus L.) in response to environmental disparity. African Journal of Biotechnology 9: 2251-2442
Kayaçetin F, Öğüt H, Oğuz H, Subaşı İ \& Deveci H (2016). Determination of the effect of row spacing and fall and spring sowing on composition of fatty acid and biodiesel fuel characteristics of Mustard (Sinapis arvensis L.). Ciência e Técnica Vitivinícola Journal (ISSN: 0254-0223) 21(11): 54-69

Kondra Z P, Campbell D C \& King R J (1983). Temperature effects on germination of Rapeseed (Brassica napus L. and B. Campestris L.). Canadian Journal of Plant Science 63: 1063-1067

Kottek M, Grieser J, Beck C, Rudolf B \& Rubel F (2006). World map of the Koppen-Geiger climate classification updated. Meteorologische Zeitschrift 15(3): 259-263

Loss S P \& Siddique K H M (1994). Morphological and physiological traits associated with wheat yield increases in Mediterranean environments. Advances Agronomy 52: 229-276

Malcolm J, Morrison D \& Stewart W (2002). Heat stress during flowering in Summer Brassica. Crop Science Society of America Crop Science 42: 797-803

Mao S, Han Y, Wu X, An T, Tang J, Shen J \& Li Z (2012). Comparative genomic in situ hybridization analysis of the genomic relationship among Sinapis arvensis, Brassica rapa and Brassica nigra. Herditas (Lund) 149(3): 86-90

Miller P, Lanier W \& Brandt S (2001). Using growing degree days to predict plant stages Montana State University http://storemsuextensionorg/publications/ Agand Natural Resources/MT200103AGpdf (Access date: 08.02.2018)

Morrison M J, McVetty P B E \& Shaykewich C F (1989). The determination and verification of baseline temperature for the growth of westar summer rape. Canadian Journal of Plant Science 69: 455-464

Pyare R, Prasad K, Dixit V, Khan N \& Sonker T C (2008). Effect of row spacings and sulphur on growth yield attributes yield and economics of mustard [Brassica juncea (L.) Czern and Coss]. Journal Plant Archives 8(2): 633-635

Qadir G, Hassan F \& Malik M A (2007). Growing degree days and yield relationship in sunflower. International Journal of Agriculture and Biology 1560-8530/2007/09-4-564-568

Saran G \& Giri G (1987). Influence of dates of sowing on Brassica species under semi-arid rainfed conditions of NORTH-WEST. India Journal of Agricultural Science 109(3): 561-566 
Schuster W \& Taghizadeh A (1981). On the yield structure of some spring rape varieties. Uber Die Ertragsstruktur Einiger Sommerrepssorten Bayerischess Landwirtschaftliches Jahrbuck 58(2): 212-216

Shafii B, Mahler K A, Price W J \& Auld D L (1992). Genotype $\mathrm{x}$ environment interaction on winter rapeseed yield and oil content. Crop Science 32(4): 922-927

Singh M P \& Lallu-Singh N B (2014). Thermal requirement of indian mustard (Brassica juncea) at different phonological stages under late sown condition. Indian Journal of Plant Physiology 19(3): 238-243

Sra S S (1978). Ertragsstruktur und qualitatsmerkmale von winter und sommer rapssorten zur kornnutzung auf ökologisch differenzierten. Standorten, Dissertation, Giessen

Stannard M, Brunty J \& Pan B (2000). Planting Dates for Autumn Cover Crops in the Irrigated Columbia Basin Technical Notes AgronomyWashingtonhttp://wwwnrcsusdagov/
Internet/FSE_PLANTMATERIALS/publications/ wapmctn440700pdf (Access date: 25.01.2018)

Turner N C, Wright G C \& Siddique K H M (2001). Adaptation of grain legumes (pulses) to water limited environments. Advances Agrononmy 71: 193-231

Wahhab M A, Mondal M R I, Akbar M A, Alam M S, Ahmed M U \& Begum F (2002). Status of oil crop production in Bangladesh. Oil seed Research Centre Bangladesh Agril Research Institute Joydebpur Gazipur pp. 9-10

Walton G P S \& Bowden B (1999). Environmental Impact on Canola Yield and Oil GCIRC. In: N. Wratten, and P. A. Salisbury, eds. Proceedings of the $10^{\text {th }}$ International Rapeseed Congress (http://www. regional.org.au/au/gcirc), Canberra, Australia 26-29 September, pp. 136-143

Wu X, Chen B, Lu G, Wang H, Xu K, Guizhan G \& Song Y (2011). Genetic diversity in oil and vegetable mustard (Brassica juncea) landraces revealed by SRAP markers. Genetic Resources and Crop Evolution 56(7): 1011-1022 